Impact of Environmental Exposures on the Mutagenicity/Carcinogenicity of Heterocyclic Amines

J. S. Felton, M. G. Knize, L. M. Bennett, M. A. Malfatti, M. E. Colvin, K. S. Kulp

December 29, 2003

Toxicology 
This document was prepared as an account of work sponsored by an agency of the United States Government. Neither the United States Government nor the University of California nor any of their employees, makes any warranty, express or implied, or assumes any legal liability or responsibility for the accuracy, completeness, or usefulness of any information, apparatus, product, or process disclosed, or represents that its use would not infringe privately owned rights. Reference herein to any specific commercial product, process, or service by trade name, trademark, manufacturer, or otherwise, does not necessarily constitute or imply its endorsement, recommendation, or favoring by the United States Government or the University of California. The views and opinions of authors expressed herein do not necessarily state or reflect those of the United States Government or the University of California, and shall not be used for advertising or product endorsement purposes. 


\section{Impact of Environmental Exposures on the Mutagenicity/Carcinogenicity of}

\section{Heterocyclic Amines}

James S. Felton ${ }^{1}$, Mark G. Knize ${ }^{1}$, L. Michelle Bennett ${ }^{2}$, Michael A. Malfatti ${ }^{1}$, Michael E. Colvin ${ }^{1}$, and Kristen S. Kulp ${ }^{1}$.

${ }^{1}$ Biology and Biotechnology Research Program, L-452, Lawrence Livermore National Laboratory, Livermore, CA 94551 USA

${ }^{2}$ Center for Cancer Research, NCI, NIH, Bethesda, MD 20892

$\underline{\text { Abstract }}$

Carcinogenic heterocyclic amines are produced from overcooked foods and are highly mutagenic in most short-term test systems. One of the most abundant of these amines, 2-amino-1-methyl-6-phenylimidazo[4,5-b]pyridine (PhIP), induces breast, colon and prostate tumors in rats. Human dietary epidemiology studies suggest a strong correlation between either meat consumption or well-done muscle meat consumption and cancers of the colon, breast, stomach, lung and esophagus. For over 20 years our laboratory has helped define the human exposure to these dietary carcinogens. In this report we describe how various environmental exposures may modulate the risk from exposure to heterocyclic amines, especially PhIP. To assess the impact of foods on PhIP metabolism in humans, we developed an LC/MS/MS method to analyze the four major $\mathrm{PhIP}$ urinary metabolites following the consumption of a single portion of grilled 
chicken. Adding broccoli to the volunteers' diet altered the kinetics of PhIP metabolism. At the cellular level we have found that PhIP itself stimulates a significant estrogenic response in MCF-7 cells, but even more interestingly, co-incubation of the cells with herbal teas appear to enhance the response. Numerous environmental chemicals found in food or the atmosphere can impact the exposure, metabolism, and cell proliferation response of heterocyclic amines.

\section{$\underline{\text { Introduction }}$}

Well-done cooking of muscle meats results in the natural formation of heterocyclic aromatic amines that have been found to be potent mutagens in various assay systems. These same compounds produce tumors at multiple organ sites in both male and female mice and rats (Shirai et al. 1997; Sugimura 1997). Furthermore, 100 percent of non-human primates given one of these heterocyclic amines (2-amino-3methylimidazo[4,5-f]quinoline; IQ) developed hepatocarcinomas after a very short latency (Adamson et al. 1994; Adamson et al. 1990). More than two thirds of human epidemiological studies (both case-control and cohort) correlating meat intake and cooking practices have shown an increased risk of cancer for individuals that prefer welldone meat. These epidemiology studies identify breast, colon, stomach and esophagus as the primary target organs. For human prostate cancer, more studies are needed to determine if meat intake is correlated with the disease. Several authors have described cooking methods such as lower temperature frying (Knize et al. 1994; Skog et al. 1995), pre-microwaving (Felton et al. 1994), marinating (Salmon et al. 1997), and frequently 
turning the meat during frying (Salmon et al. 2000) that markedly reduce the HA levels in foods.

Schwab et al. (Schwab et al. 2000) wrote a comprehensive review of compounds that may inhibit the genotoxic/carcinogenic effects of HAs. They compiled data from more than 150 reports that described more than 600 agents that attenuated the effects of HAs. Most of the agents were evaluated in SalmonellaTA98 mutation assays, but aberrant crypt foci, liver foci and DNA adducts were also used to assess in vivo effects. Protection was presumed to be a result of a number of different mechanisms, including 1) HA inactivation by a number of different mechanisms by compounds like chlorophyllin, 2) inhibition of the activating cytochrome P4501A family of enzymes, 3) induction of detoxifying enzymes, or 4) enhancement of DNA repair mechanisms. This report will not attempt to re-review these studies, but give an account of new literature studies and those primarily ongoing in our laboratory, including those which show an enhancement (increased risk) rather than an inhibition of HA effects.

We have known for many years that HAs are metabolized by cytochrome P450 1A1 and 1A2 to an $\mathrm{N}-\mathrm{OH}$ intermediate (Holme et al. 1989; Kaderlik et al. 1995) and that further metabolism by a series of conjugating enzymes is either further activating or detoxifying, depending on the specific compound (see Fig 2). It is reasonable to suspect that any polycyclic aromatic hydrocarbon, flavonoid, or other environmental inducer that changes the activity of the cytochrome P450 enzymes would impact the kinetics of HA metabolism. What is less well understood is the effect of competition at the CYP450 or other enzymatic active-site by these, and other, environmental compounds. 
Gooderham et al. (Gooderham et al. 2002) described an increased estrogenic response in cells exposed to PhIP. We have found a similar response in MCF-7 human breast cancer cells. This important finding may help explain why PhIP behaves as a complete carcinogen in rat breast tumorigenesis. Clearly, estrogenic behavior should increase cell proliferation and make the mammary cells quite susceptible to PhIP genotoxicity.

Given these very interesting data, it is important to determine the extent to which these HAs show enhanced mutagenicity or carcinogenicity when environmental compounds are given prior to or at the same time as the heterocyclic amines are consumed.

\section{Heterocyclic amine exposure}

Extensive analysis of many different kinds of foods has demonstrated the presence of heterocyclic amines in muscle meats cooked to a well-done state. Table 1 shows selected data for commonly consumed beef in North America. These data were obtained from meats cooked "well-done" in local restaurants. In the samples, MeIQx (2amino-3,8-dimethylimidazo[4,5-f]quinoxaline), PhIP, and IFP (2-amino-(1,6, dimethylfuro[3,2-e]imidazol[4,5-b]pyridine) are found at levels that vary from below the level of detection (about $0.1 \mathrm{ng} / \mathrm{g}$ ) to $19 \mathrm{ng} / \mathrm{g}$. Studies of the amounts of HAs produced in foods as a result of regional cooking practices are reported for Great Britian (Murray et al. 1993), Sweden (Johansson et al. 1994; Skog et al. 1997), Switzerland (Zimmerli et al. 2001), Spain (Busquets et al. 2003) and Japan (Wakabayashi et al. 1993). In most 
cases PhIP and MeIQx tend to be the most abundant HAs, but the levels are very dependent on the cut of the meat product and the cooking method.

\section{Metabolism in rodents and humans}

In mouse liver microsomes, PhIP is metabolized to two major metabolites, one of which is the direct-acting mutagen, $\mathrm{N} \mathrm{OH}-\mathrm{PhIP}$. Theother major mouse metabolite has a hydroxylation at the 4' position of the phenyl ring and appears to be a detoxification product (Turteltaub et al. 1989). In rat hepatocytes $\mathrm{PhIP}$ is transformed to 4'-OH PhIP as the primary product, followed by glucorindation and sulfation of this metabolite (Langouet et al. 2002; Malfatti et al. 1994). Glucuronide and sulfate conjugates of 4'-OH PhIP have been detected in human hepatocytes, but as much more minor products (Langouet et al. 2002). Thus, it is important to understand factors that favor formation of one or the other of these, as the ratio will affect the level of reactive intermediates available for DNA binding (adduct formation) and mutation. Other activation pathways besides P450 hydroxylation must be present in the mouse. Studies of transgenic CYP1A2 null mice demonstrated that PhIP was equally potent in causing lymphomas and tumors of the lung and liver in the mice lacking CYP1A2 as in wild type mice(Kimura et al. 2003). DNA adduct levels were reduced in the knockout mice, suggesting that the level of adducts is not directly correlated with the formation of blood, liver or lung tumors in this system (Snyderwine et al. 2002).

In humans, cytochrome P4501 $\mathrm{A} 2$ activation of the parent amine to the corresponding 2-hydroxyamino intermediate is the predominate step. As figure 1 shows, conjugating reactions can occur impacting the overall metabolism of the HA (Buonarati et al. 1990; Turteltaub et al. 1989). For PhIP, the N-hydroxy intermediate can be 
esterified by sulfotransferase and/or acetyltransferase to generate the highly electrophilic O-sulfony and O-acetyl esters (Buonarati et al. 1990). But unlike the rodent, human PhIP metabolism is dominated by glucuronidation. Both the $N^{2}$ and the $N 3$ positions of $\mathrm{PhIP}$ are glucuronidated directly (most likely these are non-reactive intermediates) and glucuronidation of N-hydroxy PhIP intermediates can be envisioned as a direct detoxification pathway (Malfatti et al. 2001).

\section{Foods affecting HA damage}

Table 2 reviews studies demonstrating that many foods have the potential to affect the mutagenic/carcinogenic effects of the heterocyclic amines, by a variety of mechanisms. This data represents studies published since the review by Schwab et al. (Schwab et al. 2000). With complex mixtures the exact mechanism and chemical or chemicals responsible for the effect are frequently unknown. But in some cases, specific food components are known that decrease the levels of DNA adducts, suggesting a possible protective effect for cancer initiation. DNA adducts can be relevant biomarkers of cancer risk, but as stated above, at least in the mouse, they may not always be for these tumor sites. Table 3 shows that a variety of chemicals in food reduce PhIP-DNA adducts in rodents and in many cases at the site of tumorgenesis in that species. In contrast, caffeine increased colon adducts in the rat after PhIP exposure (Takeshita et al. 2003). Much more needs to be done to understand the impact of dietary interactions, competing substrates and adduct levels on tumorgenesis. 


\section{Human studies with broccoli}

Identification of the four major metabolites of PhIP in humans allowed our laboratory to develop LC/MS/MS detection and quantification methods for these metabolites in urine after a single meal of cooked-well-done chicken (Kulp et al. 2003;

Kulp et al. 2000). Measuring changes in the amounts of total metabolites excreted or the rate of excretion of specific metabolites with time can be used to understand individual differences in metabolism, as well as whether environmental agents can impact the metabolism of PhIP.

Using this assay, we are now doing intervention studies to determine whether environmental chemicals such as isothiocyanates and/or indol-3-carbinols in broccoli and other cruciferous vegetables can impact PhIP metabolism. In a preliminary study, eight healthy men were fed a single meal of well-done chicken after abstaining from broccoli or related cruciferous vegetables for 3 days. Metabolites were determined in urine collected in $6 \mathrm{~h}$ increments. After eating cooked broccoli for 3 days, the protocol with well-done chicken was repeated. We found that the percent of the total metabolites excreted in the first $6 \mathrm{~h}$ after chicken consumption was increased in all but one individual after the broccoli intervention (Figure 2). This suggests chemicals in the broccoli increase the metabolic rate for PhIP metabolism, possibly by increasing the oxidation by P4501A2.

Murray et al. fed a group of 20 volunteers broccoli and Brussels sprouts and showed induction of CYP1A2 activity and a decrease of the parent MeIQx and PhIP in the urine (Murray et al. 2001). They did not measure the metabolites, but the finding is consistent with that from our laboratory. 


\section{Computational simulation of environmental chemical effects}

To understand the role of compounds that either induce enzyme activity or compete at the P450 active site we have begun to model the active site of human cytochrome P4501A2. This is possible by homology modeling of the structure of other P450s from rabbit and bacteria. By calculating the molecular dynamics of the docking of the small molecules into the active site we can correlate mutagenic activity of various HAs and at the same time get comparative active-site-binding parameters (Colvin et al. 1998; Sasaki et al. 2002).

\section{Inhibition of mutagenic activity in bacteria by flavonoids}

We were able to compare the inhibition of PhIP and MeIQx mutagenicity by coincubating the HAs with 2 flavonoids, naringenin and apigenin, in an Ames Salmonella typhimurium TA98 assay (Figure 3). Interestingly, although they are structurally very similar, they produced a different inhibitory response. Apigenin was able to inhibit the mutagenicity of PhIP by $90 \%$ and MeIQx by $69 \%$. Narigenin, which differs by a single

double bond, was only able to inhibit PhIP mutagenicity by $16 \%$, although the compound was more potent in the presence of MeIQx, inhibiting mutagenity by $44 \%$.

\section{Impact of a dietary supplement on PhIP induced mutagenicity, cell proliferation and estrogen response}

Fifty percent of North Americans use some form of dietary supplement, natural product, or alternative therapy (Ernst et al. 1999; Kaegi 1998; Smith et al. 1999). People 
diagnosed with cancer are motivated to try alternative products because they do not want to leave unexplored any option that could treat their cancer, prevent recurrence, or improve their quality of life (Richardson et al. 2000). The literature on dietary supplements is widely disseminated in the lay press (Percival 1994; Stainsby 1992; Whitaker 1995) and on web sites where information, presented as factual, is rarely backed by scientific investigation (Stainsby 1992). The consumers choosing to use these products are not only emotionally vulnerable to spending money on expensive products that may or may not have value, but as cancer survivors with increased risk of recurrence, may be physically vulnerable to further exposure. We are interested in understanding how breast cancer survivors who take these products while continuing to eat well-done meat may be impacting their health.

Flor-Essence ${ }^{\circledR}$ Herbal Tea is a widely consumed herbal tonic, available at health food stores and on the internet in North America. The product is a mixture of eight herbs, including burdock root (Arctium lappa), sheep sorrel (Rumex acetosella), slippery elm (Ulus rubra), Turkish rhubarb (Rheum palmatum), watercress (Nasturt officinale), blessed thistle (Carduus benedictus), red clover (Trifolum pratense) and kelp (Laminaria digitata). Individually, these herbs have been shown to have anti-carcinogenic, estrogenic, anti-estrogenic, and anti-oxidant properties, among others.

We evaluated Flor-Essence $₫$ in the Ames test to determine if the anti mutagenic activity described by others for one of its components, Turkish rhubarb (Horikawa et al. 1994; Lee et al. 1991), was detectable in this complex mixture. Using the S. typhimurium strain TA98, we determined that Flor-Essence ${ }^{\circledR}$ tea inhibits the mutagenic activity of both PhIP $(\mathrm{p}=0.04)$ and IQ $(\mathrm{p}=0.002)$ in a dose-dependent manner (Figure 4). In 
contrast, Flor-Essence ${ }^{\circledR}$ did not inhibit the mutagenicity of DMBA and benzo[a]pyrene using the TA100 S. typhimurium strain (data not shown). TA 100 is a bacterial strain that is sensitive to base substitutions, and is commonly used to quantify DMBA and benzo[a]pyrene mutagenicity. These results suggest that Flor-Essence ${ }^{\circledR}$ may be inhibiting pathways that are important for PhIP activation, while having no effect on DMBA activation.

$\mathrm{N}-\mathrm{OH}-\mathrm{PhIP}$ causes cytotoxicity in LNCaP and $\mathrm{PC} 3$ prostate cells at concentrations above $1 \mu \mathrm{g} / \mathrm{ml}$. Adding Flor-Essence ${ }^{\circledR}$ herbal tonic with the N-OH-PhIP protects prostate cancer cells from cytotoxicity (Figure 5). Cell toxicity was measured using the Cell Titer 96 Nonradioactive Cell Proliferation Kit. The results from this experiment suggest that Flor-Essence ${ }^{\circledR}$ herbal tonic may prevent the formation of DNA adducts known to be related to N-OH-PhIP-induced cytotoxicity. Taken together, these experiments suggest thatFlor -Essence ${ }^{\circledR}$ can influence PhIP-induced DNA damage in both bacterial and mammalian cells.

We have been investigating the estrogenic response in MCF-7 human breast cancer cells after PhIP exposure using computational, analytical and biochemical tools. Early data shows that PhIP induces a weak, but significant, dose-dependent activation of this response in these cells. Interestingly, Flor-Essence ${ }^{\circledR}$ herbal tonic, which is highly estrogenic in this assay system, is able to enhance the estrogenic response caused by $\mathrm{PhIP}$ in these cells. Figure 6 shows the effect of Flor-Essence ${ }^{\circledR}$ and PhIP on estrogen receptor activation in MCF-7 cells. Estrogen receptor activation is measured using a standard estrogen responsive reporter plasmid containing three vitellogenin estrogen responsive elements (EREs) upstream of the luciferase reporter gene. Flor-Essence tea at $2 \%$ 
concentration gave a $110 \%$ response that was not significantly different than physiological concentrations of estrogen. When the tea and PhIP were co-administered

the estrogen activation was $150 \%$. This was additive for the two compounds and clearly higher than estrogen alone. More work will need to be done to understand the ramifications of strong genotoxic agents like $\mathrm{PhIP}$ that may also have an effect on cell growth. Our experiments investigating the effects of an herbal supplement on PhIP exposureare an excellent example of how being exposed to complex mixtures of chemicals may have a competing effect on the ultimate risk of cancer development; in this case we see both protection and enhancement of tumorgenesis. The ultimate understanding of the effects of exposure to complex mixtures will come after we learn much more about the details and kinetics of the competing pathways.

\section{$\underline{\text { Conclusions }}$}

The impact of environmental exposures on the mutagenicity and carcinogenicity of heterocyclic amines has been shown to be significant and real. Up regulation of the cytochrome P4501A2 levels is not unexpected, as we use enzyme inducers like polychlorinated biphenyls, polycyclic aromatic hydrocarbons, and flavones to induce rodent hepatic enzyme levels in our experimental studies. From these animals we make S9 or microsomes to activate HAs for mutagenicity testing. Now, because of the sensitivity of LC/MS/MS techniques, we can study various food ingredients, such as those found in broccoli, for their ability to change the human pharmacokinetics of the HAs in different individuals. Possibly, eating cruciferous vegetables with meat could lower risk, but more needs to be done to understand these interactions fully. Finally, the 
cell proliferation activity of HAs seems enhanced with other dietary exposures, such as

specific herbal teas. Specifically, these combinations might be avoided in women

susceptible to breast cancer or those trying to prevent re-occurrence of this disease.

Understanding complex dietary exposures and competing risks should be studied in cell

culture and rodents, but the ultimate understanding of these risks will only happen when

we study humans individually and in large populations.

\section{$\underline{\text { Acknowledgements }}$}

Work performed under the auspices of the USDOE by UC, LLNL under contract W-7405-

Eng-48. This work was supported by: NCI grants CA55861 and CA94709; DOD Prostate

Cancer Research Program DAMD 17-00-1-0011; California Breast Cancer Research

Program 7IB-003 and LDRD 02-FS-006.

\section{Literature Cited}

Adamson, R.H., Takayama, S., Sugimura, T. and Thorgeirsson, U.P. (1994). Induction of hepatocellular carcinoma in nonhuman primates by the food mutagen 2-amino-3methylimidazo[4,5-f]quinoline. Environ Health Perspect 102(2): 190-3.

Adamson, R.H., Thorgeirsson, U.P., Snyderwine, E.G., Thorgeirsson, S.S., Reeves, J., Dalgard, D.W., Takayama, S. and Sugimura, T. (1990). Carcinogenicity of 2amino-3-methylimidazo[4,5-f]quinoline in nonhuman primates: induction of tumors in three macaques. Jpn. J. Cancer Res.(GANN) 81: 10-14.

Breinholt, V., Lauridsen, S.T. and Dragsted, L.O. (1999). Differential effects of dietary flavonoids on drug metabolizing and antioxidant enzymes in female rat. Xenobiotica 29(12): 1227-40.

Buonarati, M.H., Turteltaub, K.W., Shen, N.H. and Felton, J.S. (1990). Role of sulfation and acetylation in the activation of 2-hydroxyamino-1-methyl-6phenylimidazo[4,5-b]pyridine to intermediates which bind to DNA. Mutat. Res. 245: 185-190.

Busquets, R., Bordas, M., Torbino, F., Puignou, L. and Galceran, M.T. (2003). Occurrence of heterocyclic amines in several home-cooked meat dishes of the Spanish diet. J. Chrom B. In Press.

Colvin, M.E., Hatch, F.T. and Felton, J.S. (1998). Chemical and biological factors affecting mutagen potency. Mutat Res 400(1-2): 479-92. 
Dubuisson, J.G., Dyess, D.L. and Gaubatz, J.W. (2002). Resveratrol modulates human mammary epithelial cell O-acetyltransferase, sulfotransferase, and kinase activation of the heterocyclic amine carcinogen N-hydroxy-PhIP. Cancer Lett 182(1): 27-32.

Ernst, E. and Cassileth, B.R. (1999). How useful are unconventional cancer treatments? Eur J Cancer 35(11): 1608-13.

Felton, J.S., Fultz, E., Dolbeare, F.A. and Knize, M.G. (1994). Reduction of heterocyclic amine mutagens/carcinogens in fried beef patties by microwave pretreatment. Fd. Chem. Toxic. 32: 897-903.

Futakuchi, M., Hirose, M., Imaida, K., Takahashi, S., Ogawa, K., Asamoto, M., Miki, T. and Shirai, T. (2002). Chemoprevention of 2-amino-1-methyl-6-phenylimidazo[4,5-b]pyridine-induced colon carcinogenesis by 1-O-hexyl-2,3,5trimethylhydroquinone after initiation with 1,2-dimethylhydrazine in F344 rats. Carcinogenesis 23(2): 283-7.

Gooderham, N.J., Zhu, H., Lauber, S., Boyce, A. and Creton, S. (2002). Molecular and genetic toxicology of 2-amino-1-methyl-6-phenylimidazo[4,5-b]pyridine (PhIP). Mutat Res 506-507: 91-9.

Guo, D., Schut, H.A., Davis, C.D., Snyderwine, E.G., Bailey, G.S. and Dashwood, R.H. (1995). Protection by chlorophyllin and indole-3-carbinol against 2-amino-1methyl-6-phenylimidazo[4,5-b]pyridine (PhIP)-induced DNA adducts and colonic aberrant crypts in the F344 rat. Carcinogenesis 16(12): 2931-7.

He, Y.H., Friesen, M.D., Ruch, R.J. and Schut, H.A. (2000). Indole-3-carbinol as a chemopreventive agent in 2-amino-1-methyl-6-phenylimidazo[4,5-b]pyridine (PhIP) carcinogenesis: inhibition of PhIP-DNA adduct formation, acceleration of PhIP metabolism, and induction of cytochrome P450 in female F344 rats. Food Chem Toxicol 38(1): 15-23.

He, Y.H., Smale, M.H. and Schut, H.A. (1997). Chemopreventive properties of indole-3carbinol (I3C): inhibition of DNA adduct formation of the dietary carcinogen, 2amino-1-methyl-6-phenylimidazo [4,5-b]pyridine (PhIP), in female F344 rats. J Cell Biochem Suppl 27: 42-51.

Holme, J.A., Wallin, H., Bronborg, G., Soderlund, E.J., Hongslo, J.K. and Alexander, J. (1989). Genotoxicity of the food mutagen 2-amino-1-methyl-6phenylimidazo[4,5-b]pyridine (PhIP): formation of 2-hydroxy-amino-PhIP, a directly acting genotoxic metabolite. Carcinogenesis 10: 1389-1396.

Horikawa, K., Mohri, T., Tanaka, Y. and Tokiwa, H. (1994). Moderate inhibition of mutagenicity and carcinogenicity of benzo[a]pyrene, 1,6-dinitropyrene and 3,9dinitrofluoranthene by Chinese medicinal herbs. Mutagenesis 9: 523-526.

Huber, W.W., Scharf, G., Rossmanith, W., Prustomersky, S., Grasl-Kraupp, B., Peter, B., Turesky, R.J. and Schulte-Hermann, R. (2002). The coffee components kahweol and cafestol induce gamma-glutamylcysteine synthetase, the rate limiting enzyme of chemoprotective glutathione synthesis, in several organs of the rat. Arch Toxicol 75(11-12): 685-94.

Johansson, M.A.E. and Jägerstad, M.I. (1994). Occurrence of mutagenic/carcinogenic heterocyclic amines in meat and fish products, including pan residues, prepared under domestic conditions. Carcinogenesis 15: 1511-1518. 
Josyula, S., He, Y.H., Ruch, R.J. and Schut, H.A. (1998). Inhibition of DNA adduct formation of PhIP in female F344 rats by dietary conjugated linoleic acid. Nutr Cancer 32(3): 132-8.

Kaderlik, K.R. and Kadlubar, F.F. (1995). Metabolic polymorphisms and carcinogenDNA adduct formation in human populations. Pharmacogenetics 5 Spec No: S108-17.

Kaegi, E. (1998). A patient's guide to choosing unconventional therapies. Cmaj 158(9): $1161-5$.

Kimura, S., Kawabe, M., Yu, A., Morishima, H., Fernandez-Salguero, P., Hammons, G.J., Ward, J.M., Kadlubar, F.F. and Gonzalez, F.J. (2003). Carcinogenesis of the food mutagen PhIP in mice is independent of CYP1A2. Carcinogenesis 24(3): 583-7.

Knasmuller, S., Steinkellner, H., Hirschl, A.M., Rabot, S., Nobis, E.C. and Kassie, F. (2001). Impact of bacteria in dairy products and of the intestinal microflora on the genotoxic and carcinogenic effects of heterocyclic aromatic amines. Mutat Res 480-481: 129-38.

Knize, M.G., Dolbeare, F.A., Carroll, K.L., Moore II, D.H. and Felton, J.S. (1994). Effect of cooking time and temperature on the heterocyclic amine content of fried-beef patties. Fd. Chem. Toxic 32: 595-603.

Krul, C., Luiten-Schuite, A., Tenfelde, A., van Ommen, B., Verhagen, H. and Havenaar, R. (2001). Antimutagenic activity of green tea and black tea extracts studied in a dynamic in vitro gastrointestinal model. Mutation Research 474(1-2): 71-85.

Kulp, K.S., Fortson, S.L., Knize, M.G. and Felton, J.S. (2003). An in vitro model system to predict the bioaccessibility of heterocyclic amines from a cooked meat matrix. Food Chem Toxicol 41(12): 1701-10.

Kulp, K.S., Knize, M.G., Malfatti, M.A., Salmon, C.P. and Felton, J.S. (2000). Identification of urine metabolites of 2-amino-1-methyl-6-phenylimidazo[4,5b]pyridine following consumption of a single cooked chicken meal in humans. Carcinogenesis 21(11): 2065-72.

Langouet, S., Paehler, A., Welti, D.H., Kerriguy, N., Guillouzo, A. and Turesky, R.J. (2002). Differential metabolism of 2-aminl- methyl-6-phenylimidazo[4,5$b$ ]pyridine in rat and human hepatocytes. Carcinogenesis 23: 115-122.

Lee, H. and Tsai, S.-J. (1991). Effect of emodin on cooked-food mutagen activation. Fd Chem Toxic 29: 765-770.

Lin, D.X., Thompson, P.A., Teitel, C., Chen, J.S. and Kadlubar, F.F. (2003). Direct reduction of N-acetoxy-PhIP by tea polyphenols: a possible mechanism for chemoprevention against PhIP-DNA adduct formation. Mutat Res 523-524: 193200.

Malfatti, M.A., Buonarati, M.H., Turteltaub, K.W., Shen, N.H. and Felton, J.S. (1994). The role of sulfation and /or acetylation in the metabolism of the cooked food mutagen 2-amino-1-methyl-6-phenylimidazo[4,5-b]pyridine in Samlmonella typhimurium and isolated rat hepatocytes. Chem. Res. in Toxcology 7: 139-147.

Malfatti, M.A. and Felton, J.S. (2001). N-glucuronidation of 2-amino-1-methyl-6phenylimidazo[4,5-b]pyridine (PhIP) and N_hydroxy-PhIP by specific human UDP-glucuronosyltransferases. Carcinogenesis 22(7): 1087-93. 
Mori, Y., Koide, A., Kobayashi, Y., Furukawa, F., Hirose, M. and Nishikawa, A. (2003). Effects of cigarette smoke and a heterocyclic amine, MeIQx on cytochrome P450 , mutagenic activation of various carcinogens and glucuronidation in rat liver. Mutagenesis 18(1): 87-93.

Murray, S., Lake, B.G., Gray, S., Edwards, A.J., Springall, C., Bowey, E.A., Williamson, G., Boobis, A.R. and Gooderham, N.J. (2001). Effect of cruciferous vegetable consumption on heterocyclic aromatic amine metabolism in man. Carcinogenesis 22(9): 1413-20.

Murray, S., Lynch, A.M., Knize, M.G. and Gooderham, N.J. (1993). Quantification of the carcinogens 2-amino-3,8-dimethylimidazo[4,5-f]quinoxaline, 2-amino-3,4,8trimethylimidazo[4,5-f]quinoxaline, and 2-amino-1-methyl-6-phenylimidazo[4,5b]pyridine in food using a combined assay based on capillary column gas chromatography negative ion mass spectrometry. J. Chrom. (Biomedical Applications 616: 211-219.

Muto, S., Fujita, K., Yamazaki, Y. and Kamataki, T. (2001). Inhibition by green tea catechins of metabolic activation of procarcinogens by human cytochrome P450. Mutat Res 479(1-2): 197-206.

Percival, J. (1994). The Essiac Handbook. Orlando, FL, Rideout Publishing Company.

Richardson, M.A., Sanders, T., Palmer, J.L., Greisinger, A. and Singletary, S.E. (2000). Complementary/alternative medicine use in a comprehensive cancer center and the implications for oncology. J Clin Oncol 18(13): 2505-14.

Salmon, C.P., Knize, M.G. and Felton, J.S. (1997). Effects of marinating on heterocyclic amine carcinogen formation in grilled chicken. Fd. Chem. Toxic. 35: 433-441.

Salmon, C.P., Knize, M.G., Panteleakos, F.N., Wu, R., Nelson, D.O. and Felton, J.S. (2000). Minimization of heterocyclic amines and thermal inactivation of Escherichia coli in fried ground beef. Jounal of the National Cancer Institute 92: 1773-1778.

Santana-Rios, G., Orner, G.A., Xu, M., Izquierdo-Pulido, M. and Dashwood, R.H. (2001). Inhibition by white tea of 2-amino-1-methyl-6-phenylimidazo[4,5b]pyridine-induced colonic aberrant crypts in the F344 rat. Nutr Cancer 41(1-2): 98-103.

Sasaki, J.C., Fellers, R.S. and Colvin, M.E. (2002). Metabolic oxidation of carcinogenic arylamines by $\mathrm{p} 450$ monooxygenases: theoretical support for the one-electron transfer mechanism. Mutat Res 506-507: 79-89.

Schut, H.A., Cummings, D.A., Smale, M.H., Josyula, S. and Friesen, M.D. (1997). DNA adducts of heterocyclic amines: formation, removal and inhibition by dietary components. Mutat Res 376(1-2): 185-94.

Schwab, C.E., Huber, W.W., Parzefall, W., Hietsch, G., Kassie, F., Schulte-Hermann, R. and Knasmuller, S. (2000). Search for compounds that inhibit the genotoxic and carcinogenic effects of heterocyclic aromatic amines. Crit Rev Toxicol 30(1): 169.

Shirai, T., Sano, M., Tamano, S., Takahashi, S., Hirose, T., Futakuchi, M., Hasegawa, R., Imaida, K., Matsumoto, K.-I., Wakabayashi, K., Sugimura, T. and Ito, N. (1997). The prostate: A target for carcinogenicity of 2-amino-1-methyl-6-imidazo[4,5b]pyridine. Cancer Research 57: 195-198. 
Skog, K., Augustsson, K., Steineck, G., Stenberg, M. and Jägerstad, M. (1997). Polar and non-polar heterocyclic amines in cooked fish and meat products and their corresponding residues. Fd. Chem. Toxic.

Skog, K., Steineck, G., Augustsson, K. and Jägerstad, M. (1995). Effect of cooking temperature on the formation of heterocyclic amines in fried meat products and pan residues. Carcinogenesis 16: 861-867.

Smith, M. and Boon, H.S. (1999). Counseling cancer patients about herbal medicine. Patient Educ Couns 38(2): 109-20.

Snyderwine, E.G., Yu, M., Schut, H.A., Knight-Jones, L. and Kimura, S. (2002). Effect of CYP1A2 deficiency on heterocyclic amine DNA adduct levels in mice. Food Chem Toxicol 40(10): 1529-33.

Stainsby, M. (1992). Keeping hope alive. The Vancouver Sun. Vancouver.

Steinkellner, H., Rabot, S., Freywald, C., Nobis, E., Scharf, G., Chabicovsky, M., Knasmuller, S. and Kassie, F. (2001). Effects of cruciferous vegetables and their constituents on drug metabolizing enzymes involved in the bioactivation of DNAreactive dietary carcinogens. Mutat Res 480-481: 285-97.

Sugimura, T. (1997). Overview of carcinogenic heterocyclic amines. Mutat. Res. 376: 211-219.

Takahashi, M., Totsuka, Y., Masuda, M., Fukuda, K., Oguri, A., Yazawa, K., Sugimura, T. and Wakabayashi, K. (1997). Reduction in formation of 2-amino-1-methyl-6phenylimidazo[4,5-b]pyridine (PhIP)-induced aberrant crypt foci in the rat colon by docosahexaenoic acid (DHA). Carcinogenesis 18(10): 1937-41.

Takeshita, F., Ogawa, K., Asamoto, M. and Shirai, T. (2003). Mechanistic approach of contrasting modifying effects of caffeine on carcinogenesis in the rat colon and mammary gland induced with 2-amino-1-methyl-6-phenylimidazo[4,5-b]pyridine. Cancer Lett 194(1): 25-35.

Turteltaub, K.W., Knize, M.G., Healy, S.K., Tucker, J.D. and Felton, J.S. (1989). The metabolic disposition of 2-amino-1-methyl-6-phenylimidazo[4,5-b]pyridine in the induced mouse. Food Chem Toxicol 27(10): 667-73.

Ubagai, T., Ochiai, M., Kawamori, T., Imai, H., Sugimura, T., Nagao, M. and Nakagama, H. (2002). Efficient induction of rat large intestinal tumors with a new spectrum of mutations by intermittent administration of 2-amino-1-methyl-6phenylimidazo[4,5-b]pyridine in combination with a high fat diet. Carcinogenesis 23(1): 197-200.

Wagner, E.D., Marengo, M.S. and Plewa, M.J. (2003). Modulation of the mutagenicity of heterocyclic amines by organophosphate insecticides and their metabolites. Mutat Res 536(1-2): 103-15.

Wakabayashi, K., Ushiyama, H., m, T., Nukaya, H., Kim, S.-B., Hirose, M., Ochiai, M., Sugimura, T. and Nagao, M. (1993). Exposure to heterocyclic amines.

Environmental Health Perspectives 99: 129-133.

Whitaker, J. (1995). Should you take Essiac tea against cancer? Dr. Whitaker's Newsletter. 5.

Yu, Z., Xu, M., Santana-Rios, G., Shen, R., Izquierdo-Pulido, M., Williams, D.E. and Dashwood, R.H. (2001). A comparison of whole wheat, refined wheat and wheat bran as inhibitors of heterocyclic amines in the Salmonella mutagenicity assay 
and in the rat colonic aberrant crypt focus assay. Food Chem Toxicol 39(7): 65565.

Zimmerli, B., Rhyn, P., Zoller, O. and Schlatter, J. (2001). Occurrence of heterocycic aromatic amines in the Swiss diet: analytical method, exposure estimation and risk assessment. Food Additives and Contaminants 18: 533-551. 
Table 1. Heterocyclic amines are found in various quantities in restaurant-cooked meat (ng heterocyclic amine per g cooked meat).

\begin{tabular}{|c|c|c|c|c|}
\hline & Restaurant- & & & \\
\hline Sample & doneness & IFP & MeIQx & PhIP \\
\hline Top loin steak & A-well done & 7.0 & 1.3 & 7.7 \\
\hline Top loin steak & B-well done & nd & 1.3 & 0.86 \\
\hline Flank steak & C-well done & 8.2 & 1.9 & 19 \\
\hline Prime rib & C-well done & nd & nd & nd \\
\hline Beef (fajitas) & D-unspecified & 1.4 & 0.93 & 1.7 \\
\hline
\end{tabular}

nd=not detected. 
Table 2. Recent reports of foods or contaminants shown to affect HA effects in vitro or in vivo.

\begin{tabular}{|c|c|c|}
\hline Food/exposure & Effect & Reference \\
\hline $\begin{array}{l}\text { Green, black, white } \\
\text { tea }\end{array}$ & $\begin{array}{l}\text { Inhibit various enzymes, } \\
\text { Prevent DNA binding }\end{array}$ & $\begin{array}{l}\text { (Santana-Rios et al. 2001), (Krul et al. } \\
\text { 2001), (Muto et al. 2001), } \\
\text { (Lin et al. 2003), (Lin et al. 2003) }\end{array}$ \\
\hline $\begin{array}{l}\text { Cruciferous } \\
\text { vegetables }\end{array}$ & Induce GST, P4501A2 & $\begin{array}{l}\text { (Steinkellner et al. 2001), (Murray et } \\
\text { al. 2001) }\end{array}$ \\
\hline Wheat bran fiber & Lignin binding & (Yu et al. 2001) \\
\hline Coffee & $\begin{array}{l}\text { Induce glucuronosyl and } \\
\text { glutathione transferases }\end{array}$ & (Huber et al. 2002) \\
\hline Milk products & Binding to bacteria & (Knasmuller et al. 2001), \\
\hline Cigarette smoke & Induce CYP1A2 & (Mori et al. 2003) \\
\hline Fat & $\begin{array}{l}\text { Increase intestinal } \\
\text { tumors in rat }\end{array}$ & (Ubagai et al. 2002) \\
\hline $\begin{array}{l}\text { Organophosphate } \\
\text { insecticides }\end{array}$ & $\begin{array}{l}\text { Enhances mutagenic } \\
\text { response }\end{array}$ & (Wagner et al. 2003) \\
\hline
\end{tabular}


Table 3. Food components reducing PhIP-DNA adducts in rodents.

\begin{tabular}{|lll|}
\hline Food component & Target tissue & Reference \\
\hline Chlorophyllin & Colon & (Guo et al. 1995) \\
\hline Indole-3-carbinol & Colon & (Guo et al. 1995) \\
& Mammary, colon, liver & (He et al. 1997) \\
\hline Conjugated linoleic acid & Liver and mammary gland & (Schut et al. 1997), \\
& & (Futakuchi et al. 2002) \\
\hline Reservatrol & & (Dubuisson et al. 2002) \\
\hline Omega-3 fatty acids & Liver spleen small intestine in & (Josyula et al. 1998) \\
\hline B-Naphthoflavone & mouse, not rat & \\
\hline Docosahexaenoic acid & Colon & (Breinholt et al. 1999) \\
\hline
\end{tabular}


Figure Legends.

Figure 1. Pathways for the activation and detoxification of PhIP.

Figure 2. Effect of broccoli on the percent of PhIP metabolites excreted in the urine 0-6 hours after consuming well-cooked chicken. Black bar represents percent of total PhIP metabolites excreted during the 0-6 hours collection time before the broccoli intervention. Grey bars represent excretion during the same time period after the intervention.

Figure 3. Inhibition of mutagenic activitiy of MeIQx (open bar) and PhIP (filled bar) activity in Salmonella typhimurium TA98. Apigenin and naringenin differ in only a single double bond, indicated by an arrow, yet apigenin is a more potent inhibitor for both MeIQx and PhIP. Both flavonoids were used at 15 nmoles/plate.

Figure 4. Effect of Flor-Essence ${ }^{\circledR}$ on PhIP (triangle) and IQ (circle) induced mutagenicity using Salmonella typhimurium strain TA98 to test Flor-Essence ${ }^{\circledR}$ for antimutagenic activity. Flor-Essence ${ }^{\circledR}$ herbal tonic inhibits the mutagenic activity of PhIP and IQ in a dose dependent manner. The slope of each line is significant IQ $(p=0.002)$ and PhIP $(\mathrm{p}=0.04)$.

Figure 5. PhIP-induced toxicity in LNCaP and PC3 prostate cell lines is inhibited by $2 \%$ and $4 \%$ Flor-Essence ${ }^{\circledR}$ administration. Cells were treated with $1 \mu \mathrm{g} / \mathrm{ml}$ NOH-PhIP, $2 \%$ or $4 \%$ Flor-Essence ${ }^{\circledR}$, or $1 \mu \mathrm{g} / \mathrm{ml} \mathrm{NOH}-\mathrm{PhIP}$ with $2 \%$ or $4 \%$ Flor-Essence® added. In both $\mathrm{LNCaP}$ and PC3 cells $4 \%$ Flor-Essence® protects from the cytotoxic effects of NOH-PhIP. a: significantly less than control, $\mathrm{p}<0.05$; b: significantly less than control, $\mathrm{p}<0.01$; $\mathrm{c}$ : significantly greater than NOH-PhIP alone, $\mathrm{p}<0.05 \mathrm{~d}$ : significantly greater than NOH-PhIP alone, $\mathrm{p}<0.01$. 
Figure 6. Effect of PhIP and Flor-Essence ${ }^{\circledR}$ on estrogen receptor activation in MCF-7 human breast cancer cells. Data are presented as percentage of the response of estrogen. Error bars represent standard error of the mean. a: significantly greater than control, $\mathrm{p}<$ 0.01; b: significantly different than estradiol, $\mathrm{p}<0.01$. 


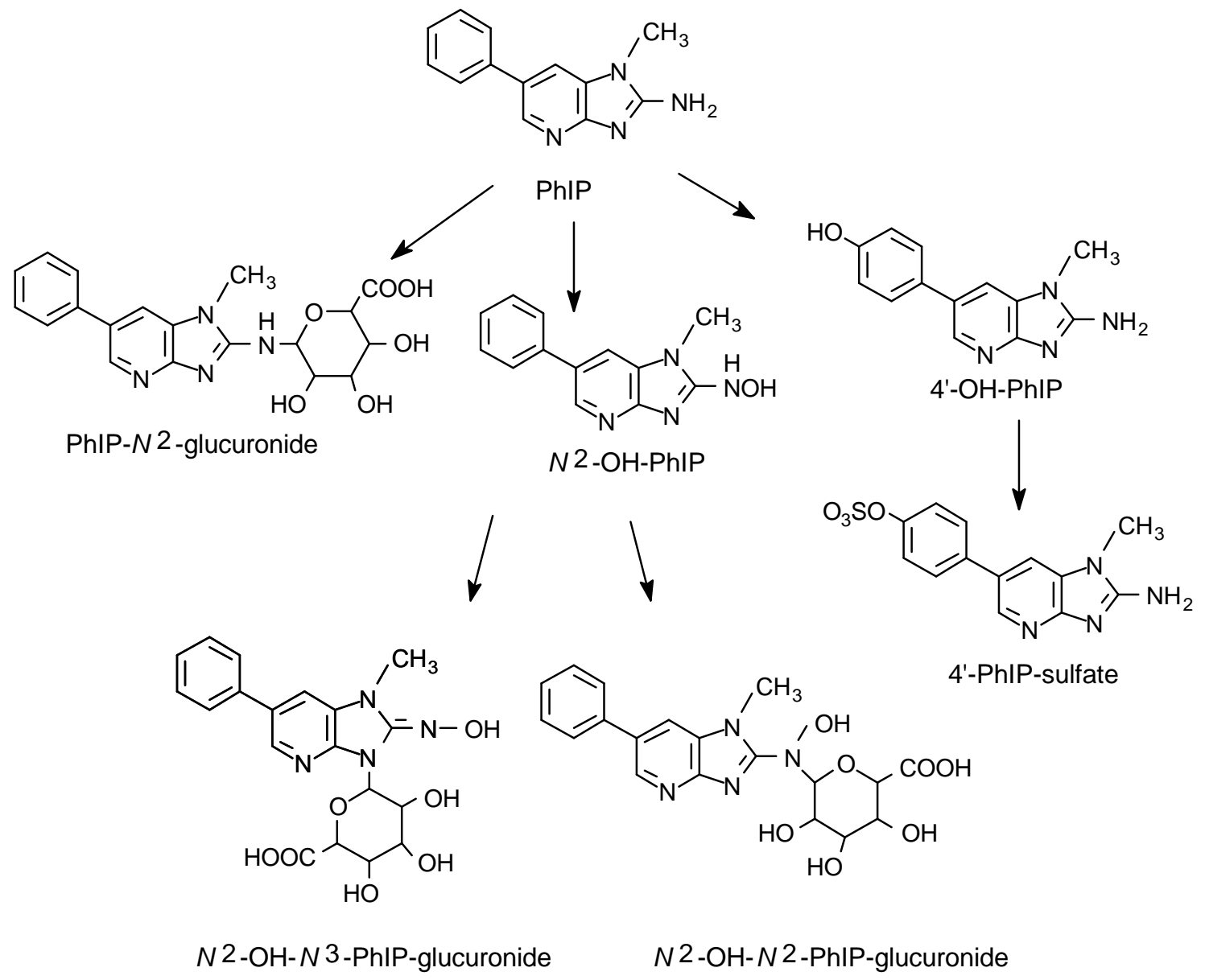




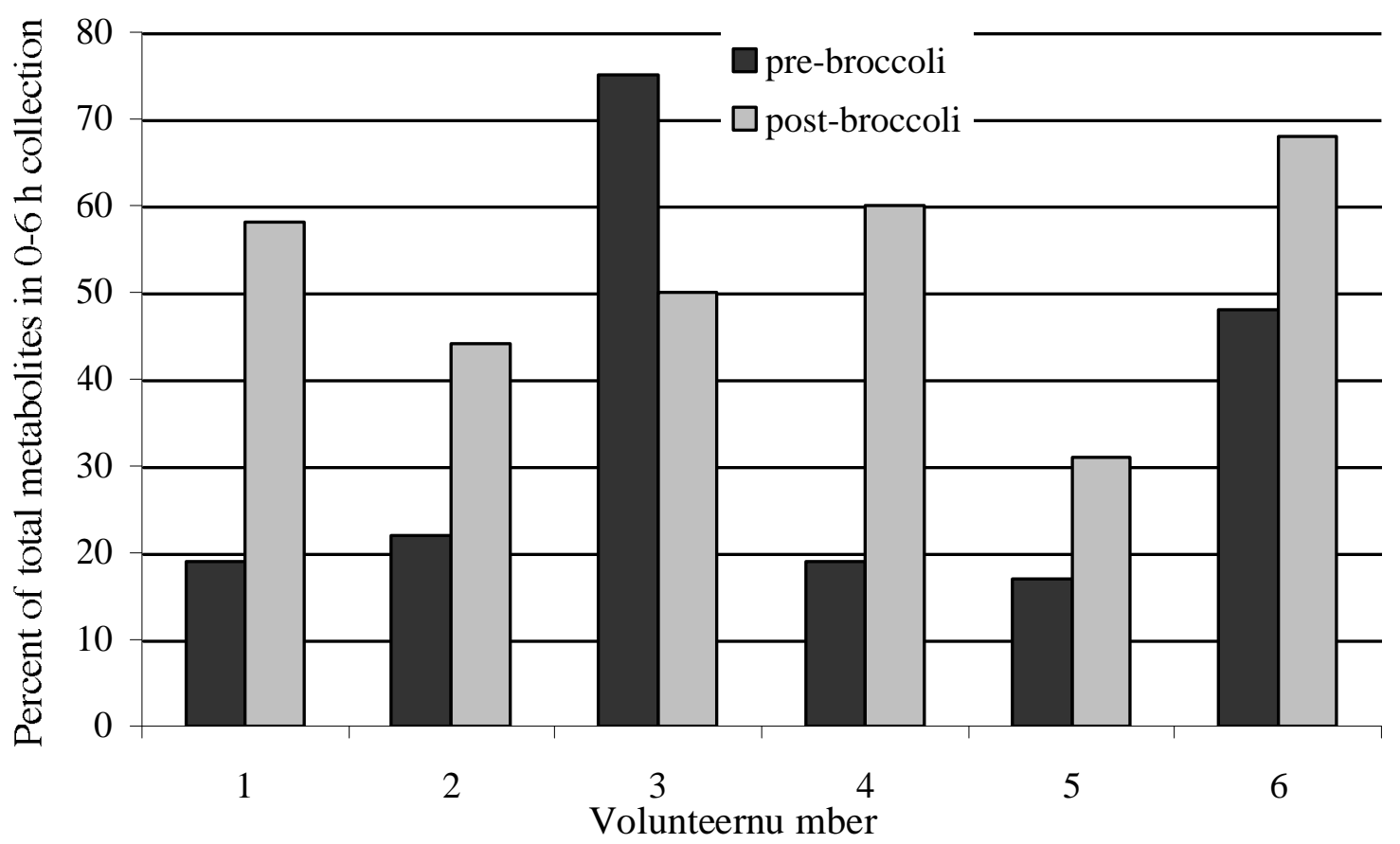




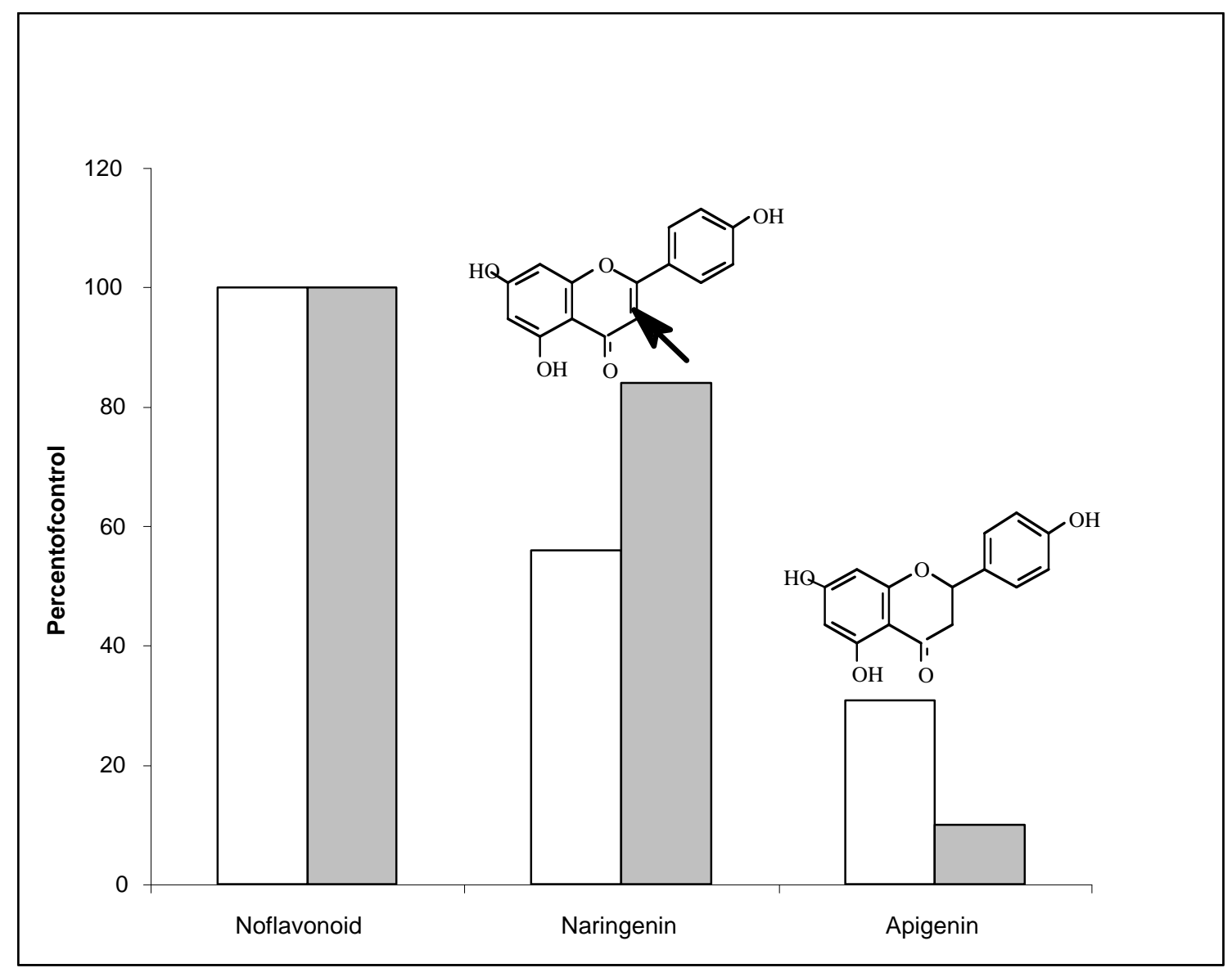




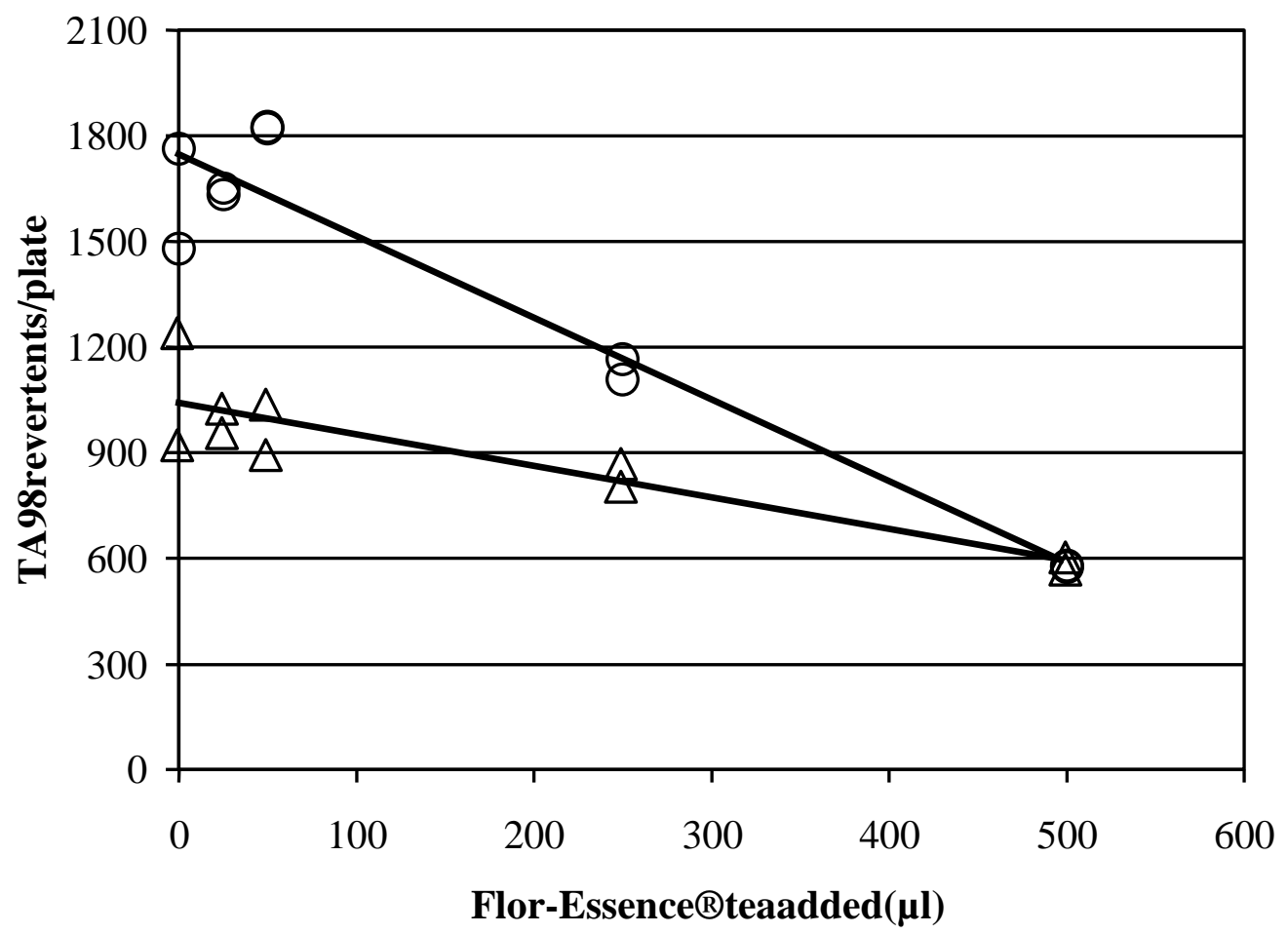




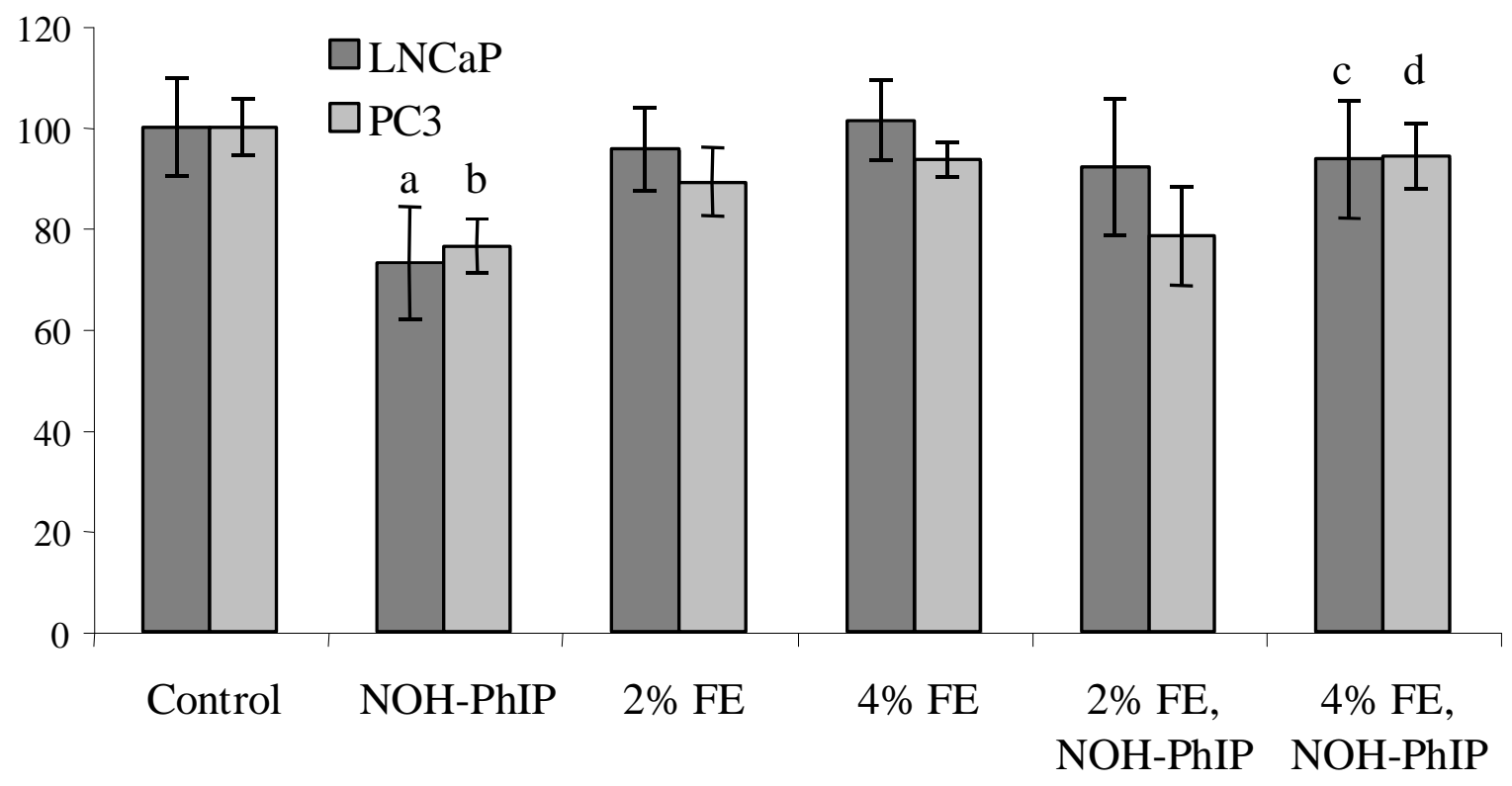




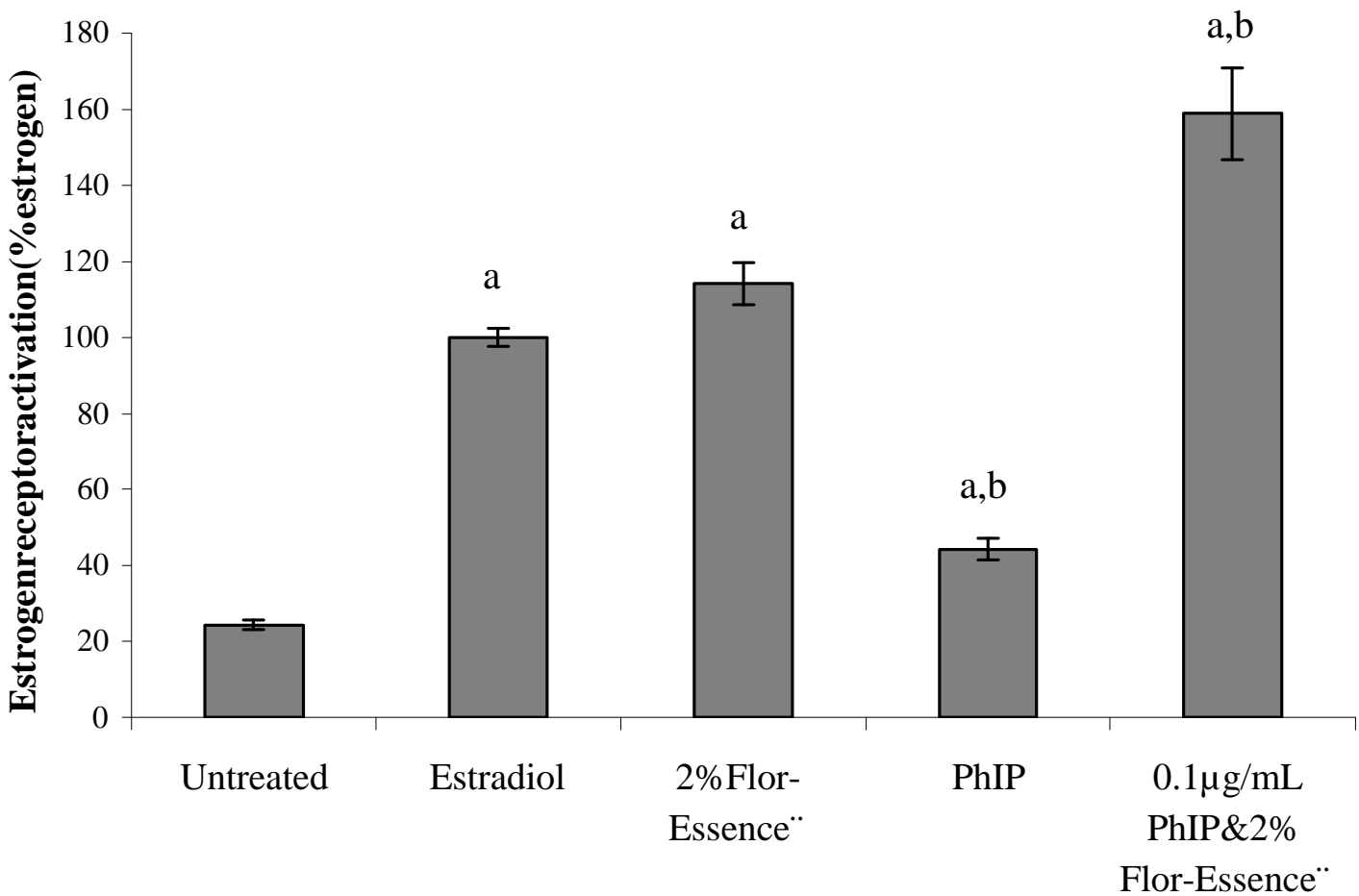

